\title{
Is chloride a conservative ion in forest ecosystems?
}

\author{
Teresia Svensson, Gary Lovett and Gene E Likens
}

\section{Linköping University Post Print}

N.B.: When citing this work, cite the original article.

The original publication is available at www.springerlink.com:

Teresia Svensson, Gary Lovett and Gene E Likens, Is chloride a conservative ion in forest ecosystems?, 2012, Biogeochemistry, (107), 1-3, 125-134.

http://dx.doi.org/10.1007/s10533-010-9538-y

Copyright: Springer Verlag (Germany)

http://www.springerlink.com/

Postprint available at: Linköping University Electronic Press

http://urn.kb.se/resolve?urn=urn:nbn:se:liu:diva-71914 
Article type: General research

Title: Is chloride a conservative ion in forest ecosystems?

Authors: Teresia Svensson ${ }^{1}$, Gary M. Lovett ${ }^{2}$, Gene E. Likens ${ }^{2}$

Affiliation: 1) Department of Thematic Studies - Water and Environmental Studies,

Linköping University, SE-601 74 Norrköping, Sweden, 2) Cary Institute of Ecosystem Studies, Box AB, Millbrook N.Y. 12545-0129, USA

* Corresponding author. E-mail: teresia.svensson@liu.se Phone: +46 11 363226, fax + 4611363292 


\section{Abstract}

Chloride $\left(\mathrm{Cl}^{-}\right)$has often been assumed to be relatively unreactive in forest ecosystems, and is frequently used as a conservative tracer to calculate fluxes of water and other ions. Recently, however, several studies have detailed cycling of $\mathrm{Cl}^{-}$in vegetation and soils. In this study $\mathrm{Cl}^{-}$ budgets are compiled from 32 catchment studies to determine the extent to which $\mathrm{Cl}^{-}$is conserved in the passage through forest ecosystems. Chloride budgets from these sites vary from net retention (input>output) to net release (output>input). In the overall data set, including those sites with very high inputs of seasalt $\mathrm{Cl}^{-}$, there was a strong correspondence between inputs and outputs. However, sites with low $\mathrm{Cl}^{-}$deposition $\left(<6 \mathrm{~kg} \mathrm{ha}^{-1} \mathrm{yr}^{-1}\right)$ consistently showed net release of $\mathrm{Cl}^{-}$, suggesting an internal source or a declining internal pool. The results indicate that $\mathrm{Cl}^{-}$may be a conservative ion in sites with high $\mathrm{Cl}^{-}$deposition, but in sites with low deposition $\mathrm{Cl}^{-}$may not be conservative. We discuss the possible causes of the $\mathrm{Cl}^{-}$imbalance and reasons why $\mathrm{Cl}^{-}$may not be conservative in ecosystem functions. 


\section{Introduction}

Beginning with the work of Eriksson (e.g. 1955), chloride $\left(\mathrm{Cl}^{-}\right)$export from catchments in streamflow has been considered to be controlled primarily by $\mathrm{Cl}^{-}$inputs in precipitation. Chloride is assumed in many studies to be largely unreactive in ecosystems, with little uptake or release by vegetation or soils (Schlesinger 1997). Chloride is often used as a conservative tracer in catchment mass balance studies, in that the increase in concentration in $\mathrm{Cl}^{-}$as water moves through the ecosystem from precipitation to stream water is taken to be an indicator of water loss by evapotranspiration and is used to calculate water residence times (e.g. Kirchner 2003) and mass balances of other, non-conservative elements (e.g. Hedin et al. 1995). Mass balances of $\mathrm{Cl}^{-}$in ecosystems have long been used for calculating water and solute transport (Lockwood et al. 1995), but are also used for risk assessments for e.g. nuclear waste (Campbell et al. 2003). The few studies that have focused specifically on $\mathrm{Cl}^{-}$transport do indicate that there can be imbalances in catchment $\mathrm{Cl}^{-}$budgets, which are typically attributed to unmeasured dry deposition (Juang and Johnson 1967), mineral weathering (Peters 1991) or interactions with vegetation and soil (Lovett et al. 2005; Öberg et al. 2005a; Öberg and Sandén 2005b; Svensson et al. 2007).

Several recent studies have indicated that, rather than being unreactive, $\mathrm{Cl}^{-}$participates in a complex biogeochemical cycle (Öberg et al. 2005a; Öberg et al. 2005b; Bastviken et al. 2007; Bastviken et al. 2009). Chloride can be immobilized in ecosystems by several different processes, including (1) ion exchange (Larsson and Jarvis 1999), (2) adsorption onto iron and aluminum oxides (Nodvin et al. 1986), (3) uptake by biota, including vegetation and microbes (Ohrui and Mitchell 1996; Lovett et al. 2005; Bastviken et al. 2009), and (5) conversion to organic forms of chlorine (Clutterbuck et al. 1940; Myneni 2002; Bastviken et al. 2007). 
These processes may result in net retention of $\mathrm{Cl}^{-}$in ecosystems on varying time scales when internal chlorine pools are increasing in magnitude or net release of $\mathrm{Cl}^{-}$when internal pools are declining. In addition, $\mathrm{Cl}^{-}$can be released by rock weathering from some bedrock types, providing an ecosystem input in addition to atmospheric deposition (Peters and Ratcliffe 1998; Lovett et al. 2005).

In this study, $\mathrm{Cl}^{-}$mass balances for a range of catchments are compared to examine the extent to which $\mathrm{Cl}^{-}$outputs reflect $\mathrm{Cl}^{-}$inputs. Included data originate mainly from forested catchments in eastern North America and Europe spanning a wide range of climatic, hydrologic, geologic, and vegetation conditions. Our objective is to provide a framework for understanding relative controls on $\mathrm{Cl}^{-}$mass balances, including the importance of sources and sinks in vegetation and soils. Additionally, we evaluate the limitations in data collection and analysis techniques used to compute the mass balances across a broad range of environmental conditions.

\section{Materials and methods}

Data were obtained from catchments in the North Temperate forest region (Table 1, Fig. 1). We added three nonforested catchments in Wales to increase the number of sites with very high $\mathrm{Cl}$ - deposition. In most cases, the data had previously been published and we cite the reference in the text; if unpublished or supplementary data were included we state that in the text (see Table 1).

\section{The catchments}

The catchment studies were chosen based on availability of data, catchment size, land-use, $\%$ surface water, and sampling interval. Only small $\left(<5 \mathrm{~km}^{2}\right)$, catchments that were free of recent 


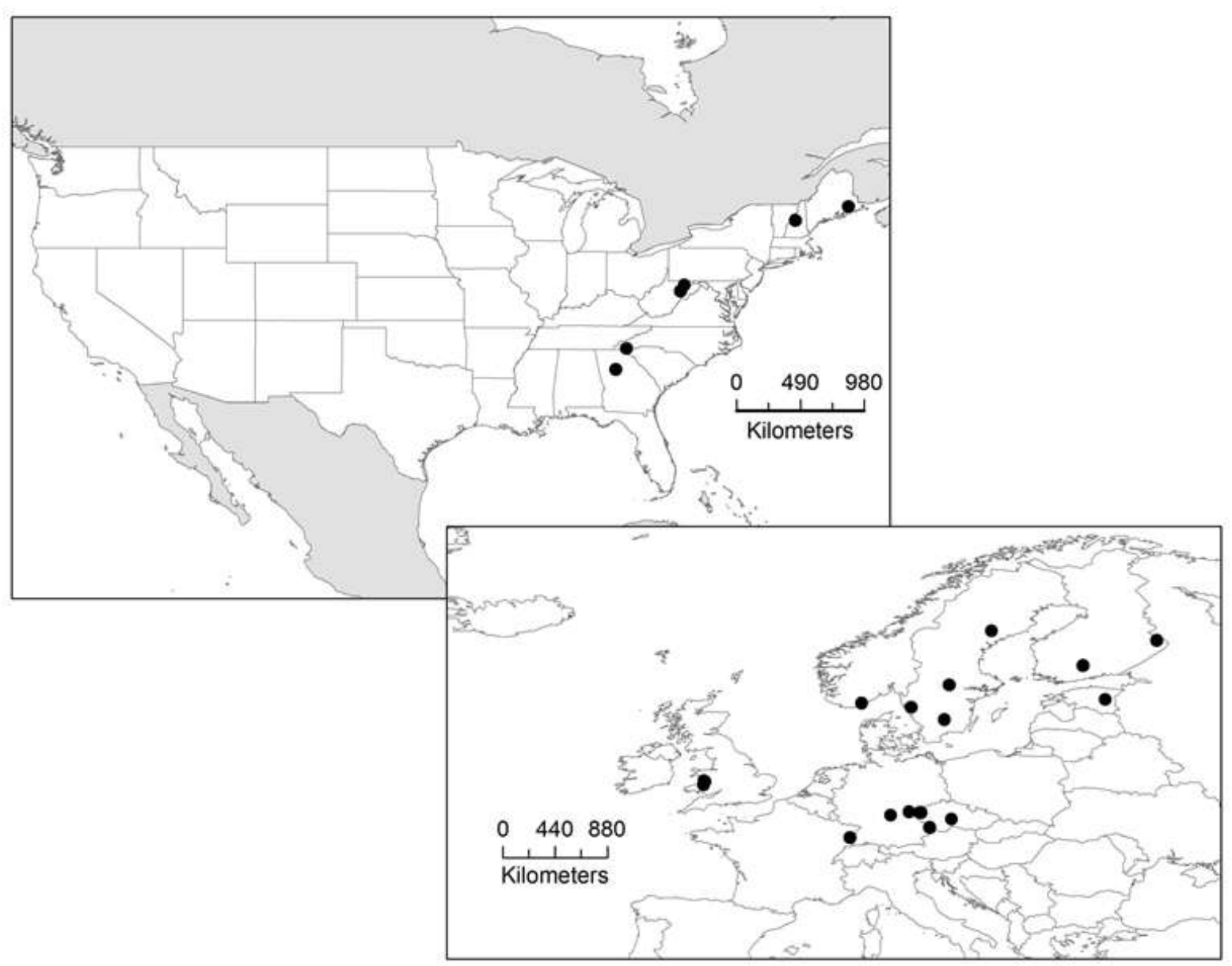

Figure 1. Map of Europe and North America showing locations of catchment sites.

large-scale physical disturbance and free of road salt application were considered. These criteria eliminated local differences in $\mathrm{Cl}^{-}$export related to deforested or developed land. Also, only catchments with streamwater chemical sampling intervals of three weeks or less were chosen to ensure that seasonal patterns and higher flow events were adequately represented. Thirty-two catchments were identified at 23 sites located in the Czech Republic, Estonia, Finland, France, Germany, Norway, Sweden, United States, and Great Britain. All of the catchments were forested except three catchments in Wales, Llyn Brianne and the two catchments at Plynlimon, which were included to improve the number of sites having high $\mathrm{Cl}^{-}$ deposition. Details about the catchment characteristics are given in Table 1. 


\section{Input and output data}

In the catchment studies, annual inorganic $\mathrm{Cl}$ budgets were compiled using existing flux data or stream and precipitation volume and chemistry data. These data cover in most cases a period of over 10 years (range: 1-33 years) (Table 1). For input estimates, some of the data sets included throughfall (13 sites), and others included bulk deposition (18 sites) and one had only wet-only deposition (Panola Mountain). Bulk deposition is collected in a continuously open funnel, and as such it collects wet deposition and the portion of the dry deposition that impacts on the walls of the funnel or falls into the funnel by gravity (Likens and Bormann 1995). None of the catchments had independent estimates of $\mathrm{Cl}^{-}$dry deposition. We consider the $\mathrm{Cl}^{-}$balances to be more complete in those catchments that had throughfall data because dry deposition and cloud-water deposition are washed off the canopy in throughfall and therefore included in the throughfall measurement. Inputs are underestimated by wet-only or bulk deposition measurements, which do not include all of the dry and cloud deposition. Cloudwater was collected at the Welsh sites, with the four catchments (Reynolds et al. 1997; Neal et al. 2004; Neal et al. 2010), but the atmospheric input was estimated based on a modeled term for cloud water inputs because the cloudwater collector was not designed to give a correct estimate of the areal average volume of cloudwater. We noted on our graphs which catchments had throughfall data and which did not.

Output was estimated from streamwater data for the catchments. Details of the data set are given in Table 1. 


\section{Results}

The annual average precipitation for the catchments ranged from $750 \mathrm{~mm}$ at Steinkreuz catchment (Germany) to $2650 \mathrm{~mm}$ at Upper Hafren catchments (Wales, UK).

The $\mathrm{Cl}^{-}$inputs and outputs vary from year to year, and in most cases in this data set we were able to average across several years (Table 1.). There was a large variation in $\mathrm{Cl}^{-}$input in the data set, although most of the sites were below $20 \mathrm{~kg} \mathrm{ha}^{-1} \mathrm{yr}^{-1}$ (Fig. 2). The median $\mathrm{Cl}^{-}$input was $6 \mathrm{~kg} \mathrm{ha}^{-1} \mathrm{yr}^{-1}$. The $\mathrm{Cl}^{-}$input was lowest at Hietajärvi (Finland) with average annual input of $1 \mathrm{~kg} \mathrm{ha}^{-1} \mathrm{yr}^{-1}$. The highest input was at Nant Tanllwyth (Wales, UK) at $175 \mathrm{~kg} \mathrm{ha}^{-1} \mathrm{yr}^{-1}$.

The $\mathrm{Cl}^{-}$budgets in this study show that the sites varied from net release to net retention of $\mathrm{Cl}^{-}$. In general, there were more sites (app. 70\%) showing a net release than those showing a net retention of $\mathrm{Cl}^{-}$. Less than half of the catchments (40\%) were in balance to within $\pm 10 \%$ (i.e., (input-output)/input <0.1) (Fig. 3). The imbalance reached as high as $-123 \%$ for one catchment (Valkea-Kotinen).

The catchment data show strong relationships between $\mathrm{Cl}^{-}$inputs and outputs (Fig. 2). A simple linear regression of the data show a $\mathrm{R}^{2}$ of $0.99(\mathrm{p}<0.001)$ and the $1: 1$ line is within the $95 \%$ confidence interval of the regression line. That means when the entire data set is considered, the $\mathrm{Cl}^{-}$output in general reflects the $\mathrm{Cl}^{-}$input. Closer examination of the data with low $\mathrm{Cl}^{-}$input (i.e. $<25 \mathrm{~kg} \mathrm{ha}^{-1} \mathrm{y}^{-1}$ ), suggests that the slope diverges more from the 1:1 slope. In order to emphasize the shape of the relationship between the two variables and to more objectively analyse where the $\mathrm{Cl}$ budget data are diverging, we fit the data with a LOESS curve (Epanechnikov kernel with 90\% smoothing) created in SPSS (SPSS Statistics 17.0). The LOESS curve through the data draws attention to a deviation from the 1:1 line for the 
catchment data receiving less than approximately $6 \mathrm{~kg} \mathrm{ha}^{-1} \mathrm{y}^{-1}$ (Fig. 2b). For catchments with $\mathrm{Cl}$ deposition input more than $6 \mathrm{~kg} \mathrm{ha}^{-1} \mathrm{y}^{-1}$ the curve approximates the $1: 1$ line.

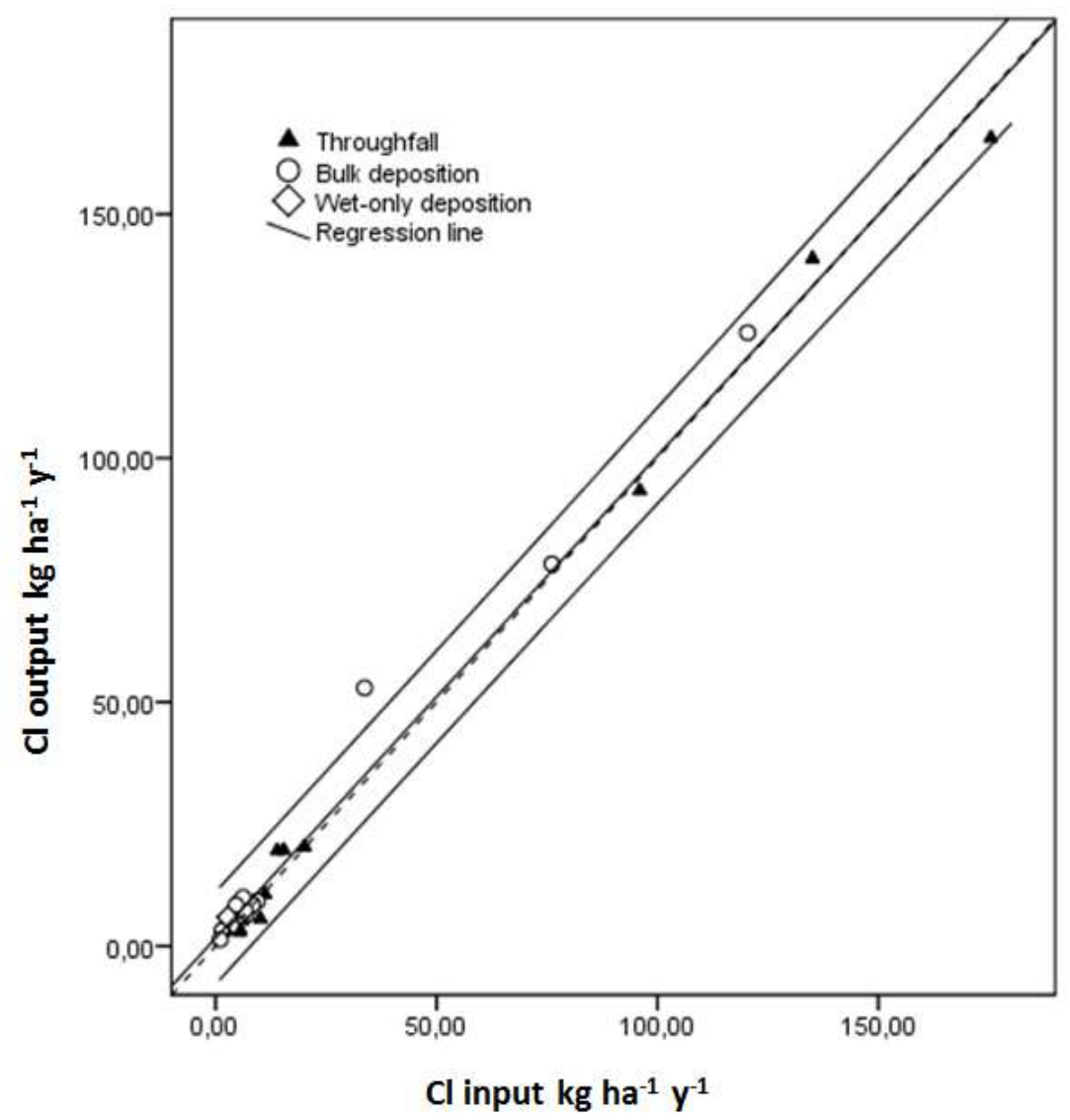

Figure 2a. Relationship between chloride inputs and outputs for all investigated catchments. The triangles represent sites that used throughfall, the circles represent sites that used only bulk deposition for the estimate of input, and the diamond represents a site that used only wetonly deposition. The linear regression line and its $95 \%$ confidence limits are shown.

For the sites that had multiple years of input and output data, in some cases the net balance was consistently positive or negative, but in other sites the sign of the net balance varied from year-to-year. The Hubbard Brook Experimental Forest (New Hampshire, USA) had the longest record, and it switched from net retention (input > output) of $\mathrm{Cl}^{-}$for most years prior to 1981 to net release (output > input) for most years after 1981. Lovett et al (2005) interpreted this pattern to be the result of a reduction of the sink associated with forest growth 
in the catchment. Other sites in our data set changed back and forth between net retention and net release in different years without any obvious pattern, possibly related to hydrologic conditions in the catchment, although there is no clear relationship between net flux and precipitation amount in the data $\left(\mathrm{R}^{2}=0.0016\right)$.

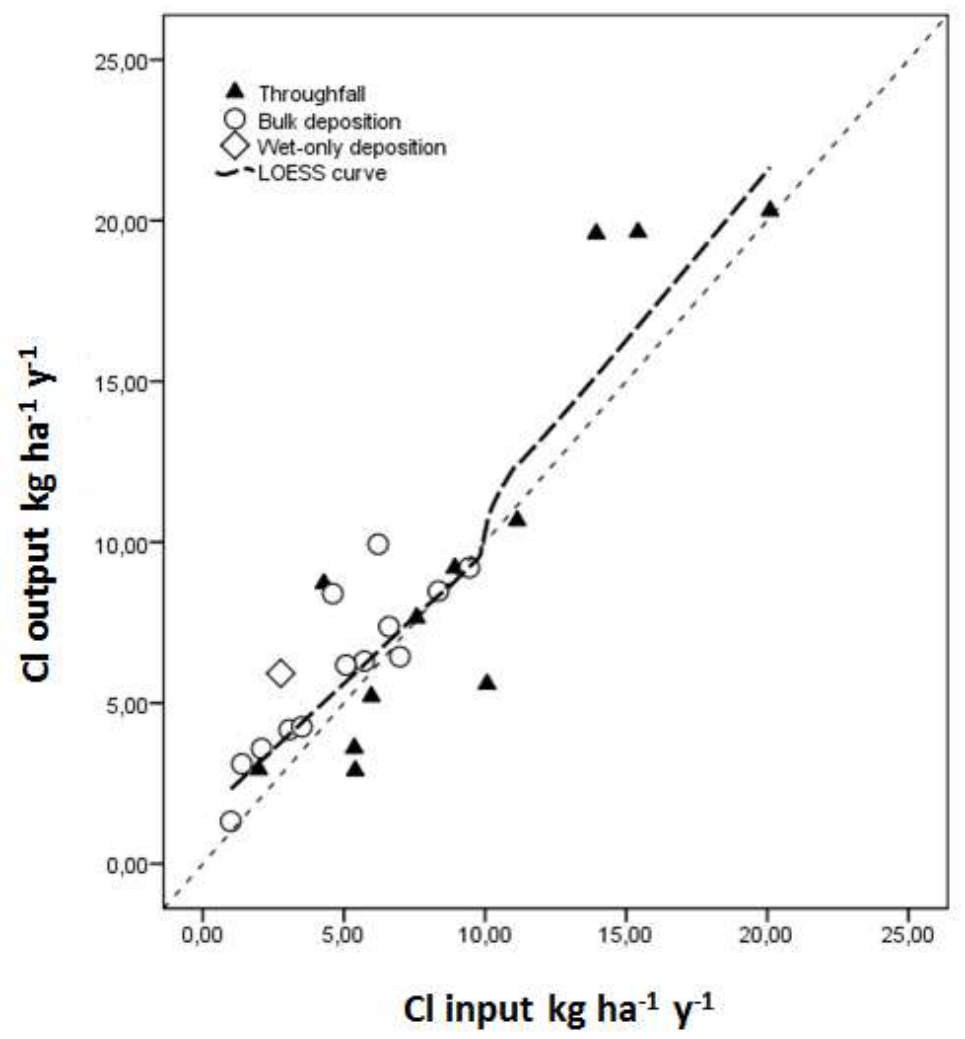

Figure $2 \mathrm{~b}$. Input and output data for catchments with input $<25 \mathrm{~kg} / \mathrm{ha} / \mathrm{y}$. The LOESS curve is the dashed line through the data. The dotted line is the 1:1 line. 


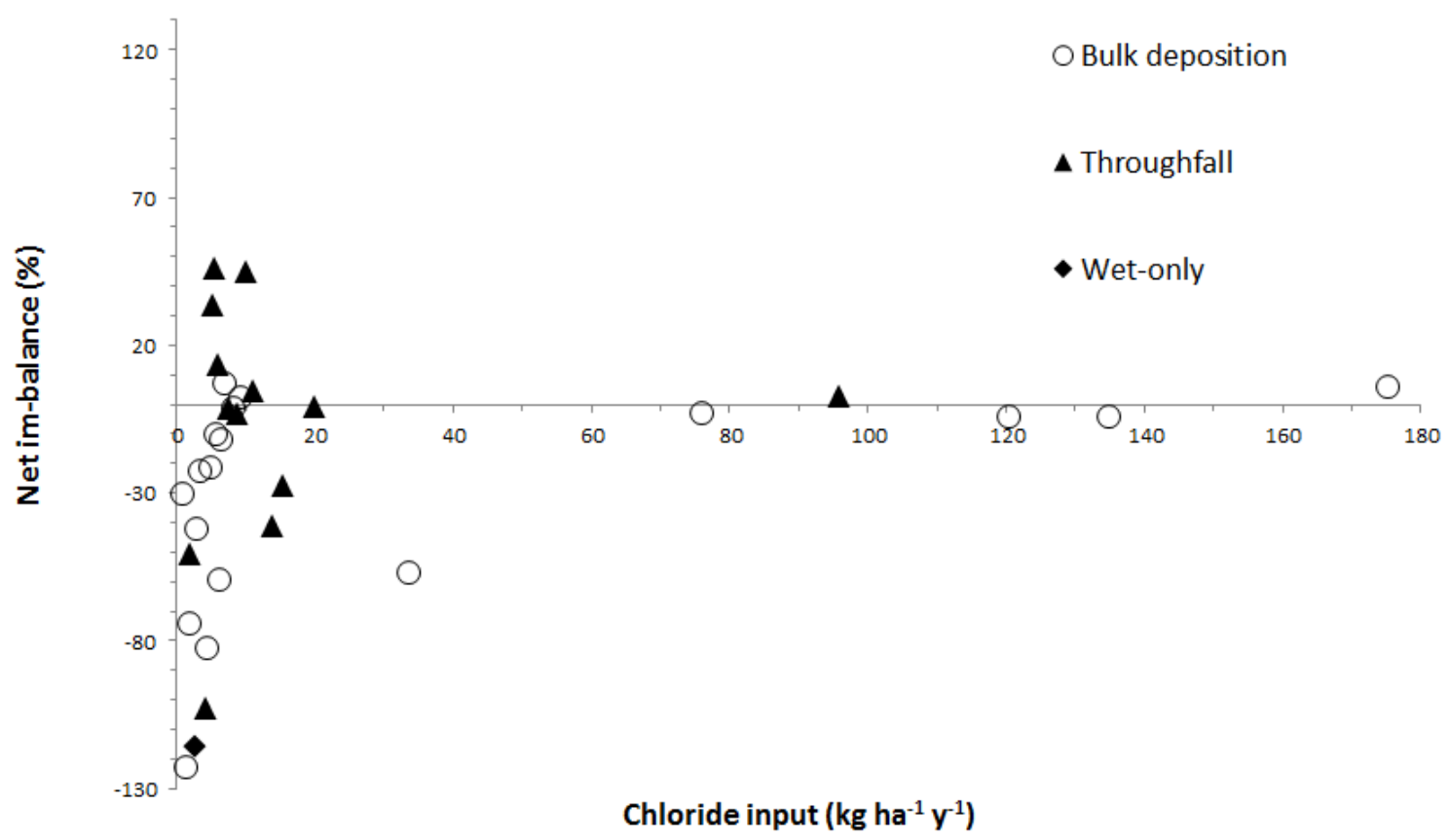

Figure 3. The $\%$ net balance ((input-output)/input)*100) of chloride in each catchment versus input for each catchment. A positive $\%$ means a net retention of chloride and a negative $\%$ means a net loss of chloride. A higher $\%$ means a larger imbalance in the chloride budget.

\section{Discussion}

The quality of $\mathrm{Cl}^{-}$data is critical in calculations of mass balances of solutes and calculations of water transport. Small imbalances could result from measurement errors. In this study, almost half of the sites have imbalances of greater than $25 \%$, and such large deviations could represent sources or sinks of $\mathrm{Cl}^{-}$in the ecosystems, which would have major implications for solute transport and water balance calculations that assume that $\mathrm{Cl}^{-}$behaves conservatively. 
Overall, the catchment data show a strong 1:1 relationship between $\mathrm{Cl}^{-}$inputs and outputs, but for catchments with low $\mathrm{Cl}^{-}$deposition $\left(<6 \mathrm{~kg} \mathrm{ha}^{-1} \mathrm{yr}^{-1}\right)$ outputs are almost always greater than inputs. Does this apparently nonconservative behaviour result from methodological problems or real sources and sinks of $\mathrm{Cl}^{-}$in the ecosystems?

Methodological issues in measuring ecosystem inputs and outputs are well known. Atmospheric inputs consist of wet deposition $\left(\mathrm{Cl}^{-}\right.$dissolved in precipitation), dry deposition (direct deposition of gaseous and particulate $\mathrm{Cl}^{-}$) and at some sites, cloud-water deposition ( $\mathrm{Cl}^{-}$dissolved in cloud droplets that deposit directly to vegetation) (Lovett 1994).

Measurements of dry and cloud water deposition are particularly vexing. For atmospheric deposition estimates, ecological studies typically use some combination of the following measurements: (1) wet-only precipitation in collectors that are open only during precipitation events, (2) bulk deposition in continuously open collectors, which collect wet deposition and the fraction of the dry deposition that results from particles large enough to settle from the atmosphere, (3) dry deposition of particles estimated from atmospheric concentration measurements and deposition models, and (4) throughfall and stemflow measured using funnels and tree collars below the canopy. Throughfall plus stemflow fluxes provide an integrative measure of total deposition to the canopy, assuming there is minimal leaching or uptake of $\mathrm{Cl}^{-}$by the canopy (Hultberg and Grennfelt 1992). Canopy leaching of $\mathrm{Cl}^{-}$is usually negligible (Lovett et al. 2005). In this study we used throughfall, when available (in 13 catchments), as the best estimate of total $\mathrm{Cl}^{-}$input. Because some of the catchment studies in our study did not have throughfall data, we estimated inputs using bulk deposition or wet-only deposition, whichever was available. Including any unmeasured dry deposition in these input estimates would move those points represented by circles and squares to the right on Fig. 2a and 2 b. For the nine catchments in our data set that have both throughfall data and bulk 
deposition data, we estimated the contribution of dry deposition (calculated as throughfallbulk deposition) to the total throughfall deposition and found it to range from 15 to $75 \%$ (mean $43 \%$ ) of the total throughfall deposition. Because of this variation it is difficult to estimate how much the bulk deposition points in the graphs would change if dry deposition were known and included in the deposition estimate.

Output estimates are also problematic. For these catchment sites, export is estimated as the product of the streamflow (measured at a stream gauging site at the outlet of the catchment) and the $\mathrm{Cl}^{-}$concentration in stream water measured at the same site. Because stream output can be episodic, the frequency of measurement may affect the accuracy of the export estimates. Stream water concentrations of $\mathrm{Cl}^{-}$vary with streamflow in some watersheds (e.g. Peters et al. 1998) but not in others (e.g Johnson et al. 1969). Rainfall and throughfall can decrease the soil water and streamwater concentrations of $\mathrm{Cl}^{-}$through dilution, but may also increase the $\mathrm{Cl}^{-}$concentration through movement of soil water with high $\mathrm{Cl}^{-}$concentrations (Peters et al. 1998). However, the relationship is more complicated as it has also been observed that concentrations may vary seasonally, probably because of different soil conditions and water transport processes (Peters et al. 1998; Kirchner 2003; Lovett et al. 2005; Svensson et al. 2007) or vegetation uptake (Lovett et al. 2005). Seasonal and stream flow variability certainly have an effect when estimating short-term $(<1 \mathrm{yr})$ output fluxes, but when several years are averaged the errors are small (Alewell et al. 2004).

Few of the catchment studies have attempted to evaluate uncertainty in the measurements. However, at one of the best-studied sites, Hubbard Brook Experimental Forest in New Hampshire, USA, the analytical uncertainty for chloride determination has been estimated to be less than 5\% (Buso et al. 2000) and the uncertainty of water flux measurements in 
precipitation and stream flow is also estimated to be less than 5\% (Bailey et al. 2003). Uncertainty for the dry deposition component at this site is unknown but is would be substantially higher (Lovett et al. 2005). The uncertainties in input and output measurements are not unique to chloride, and in fact would be at least as large for budgets of other ions, although the issue is rarely addressed.

Given these uncertainties in the inputs and outputs, we suggest that the most reliable conclusions can be drawn from general patterns of chloride budgets across sites, rather than from the budget for any individual site.

\section{Is chloride conservative?}

Considering the data set as a whole, there is a strong 1:1 relationship between $\mathrm{Cl}^{-}$inputs and outputs, indicating a conservative behaviour of chloride in the forests. However, for sites with low $\mathrm{Cl}^{-}$inputs $\left(<6 \mathrm{~kg} \mathrm{ha}^{-1} \mathrm{yr}^{-1}\right)$, which includes about a third of the catchments in this study, there is a consistent net release of $\mathrm{Cl}^{-}$in the catchment data sets. This pattern was observed even for the two low-deposition sites that used throughfall as an estimate of deposition. This net release could be due to unmeasured inputs from rock weathering, but the fact that the discrepancy in the $\mathrm{Cl}^{-}$balance is pervasive at low-deposition sites and that $\mathrm{Cl}^{-}$in bedrock is rare suggests that another factor may be responsible, likely a net decline in an ecosystem $\mathrm{Cl}^{-}$ pool. Vegetation can contain an appreciable pool of $\mathrm{Cl}^{-}$, and aggrading vegetation can sequester $\mathrm{Cl}^{-}$while vegetation disturbance can release that $\mathrm{Cl}^{-}$(Lovett et al. 2005). In this data set, because the net release is occurring across many catchments with forests of different ages and vegetation types, vegetation is not likely to be the major control. More likely it is a net release of $\mathrm{Cl}^{-}$from the soil pool. This release could occur through desorption of $\mathrm{Cl}^{-}$that was previously adsorbed to iron and aluminium oxides (Nodvin et al. 1986), especially if soil 
solution concentrations were decreasing. Another possibility is net release of $\mathrm{Cl}^{-}$from soil organic matter (SOM). The $\mathrm{Cl}^{-}$can be bound into SOM as organochlorine compounds created by microbial action (Myneni 2002; Bastviken et al. 2007; Ortiz-Bermudez et al. 2007) and the $\mathrm{Cl}^{-}$can be re-mineralized as SOM is decomposed. If the mass of SOM or the $\mathrm{Cl}: \mathrm{C}$ ratio were declining, there would be a net release of $\mathrm{Cl}^{-}$over time. The data from low-input sites in this study suggest some leaching of that $\mathrm{Cl}$ as the inorganic $\mathrm{Cl}^{-}$ion, but the $\mathrm{Cl}$ could also be leached in an organic form, and in fact organically bound $\mathrm{Cl}$ has been found in both soil water and stream water (Asplund and Grimvall 1991; Rodstedth et al. 2003). However, we are aware of only one study that has analysed the output of organically bound $\mathrm{Cl}$ on a catchment scale, and the output flux of organically bound $\mathrm{Cl}$ was only a few percent of the $\mathrm{Cl}^{-}$fluxes (Svensson et al. 2007).

In the past decade, studies have revealed that $\mathrm{Cl}^{-}$participates in a complex biogeochemical cycle (Asplund et al. 1991; Winterton 2000; Lee et al. 2001; Myneni 2002; Öberg 2002), involving for example, formation and degradation of chlorinated organic matter (consumption and release of $\mathrm{Cl}^{-}$), volatilization, leaching and precipitation (Asplund et al. 1993; Öberg and Grön 1998; Dimmer et al. 2001; Hoekstra et al. 2001; Johansson et al. 2001; Rodstedth et al. 2003; Öberg et al. 2005a). Areas receiving rather high $\mathrm{Cl}^{-}$deposition (30-50 $\left.\mathrm{kg} \mathrm{ha}^{-1} \mathrm{yr}^{-1}\right)$ on the west coast in Sweden have a higher amount of chlorinated organic matter in the soil than sites on the east coast receiving $\mathrm{Cl}^{-}$amounts of less than $5 \mathrm{~kg} \mathrm{ha}^{-1} \mathrm{yr}^{-1}$ (Johansson et al. 2003). In addition, a soil-column study showed that long soil water residence time and high $\mathrm{Cl}^{-}$load gave higher initial retention and subsequent release rates of $\mathrm{Cl}^{-}$in soils (Bastviken et al. 2006). It is therefore without doubt that $\mathrm{Cl}^{-}$can be retained and released within the soil, but how such processes affect mass balances at the watershed or plot scale has not been thoroughly investigated. 
It is unclear why a net release was observed predominantly in the low-deposition sites in our data set. One possibility is that it is in fact happening at most sites, but is easier to observe in the low-deposition sites because the input and output fluxes are smaller. In areas receiving very large loads of seasalt, the $\mathrm{Cl}^{-}$output almost equals the input, but this balance does not preclude internal cycling of $\mathrm{Cl}^{-}$(Kelly et al. 2008). The portion of the $\mathrm{Cl}^{-}$flux that would participate in ecosystem retention or release processes is negligible in environments with very high $\mathrm{Cl}^{-}$deposition, compared to environments with low $\mathrm{Cl}^{-}$deposition where it could have major influence.

Another possibility for the net release being observed mainly in low-deposition sites is that release from the SOM or sorbed $\mathrm{Cl}$ pools may be caused by reduction in $\mathrm{Cl}^{-}$in soil solution associated with reductions in $\mathrm{Cl}^{-}$deposition. The sites in this study are in eastern North America and Europe, where reduction in $\mathrm{Cl}^{-}$deposition has occurred in recent decades as a result of efforts to reduce sulfur emission from power plants, because the processes that remove sulfur also remove $\mathrm{HCl}$ (Lovett et al. 2005). It is likely that our high-deposition sites receive most of their $\mathrm{Cl}^{-}$deposition from marine sources, whereas the lower-deposition sites may receive a substantial fraction of their inputs from pollution sources. Because the pollution sources have declined but the marine sources have remained relatively constant, the release of $\mathrm{Cl}^{-}$would be most evident in low-deposition systems.

Chloride is a generally highly abundant in soil and retention and mineralization of the anion in soil organic matter appears to be common (Bastviken et al. 2007). Therefore we are not surprised to see effects of such processes at the catchment scale. On the other hand the major driving variables for those processes are unknown, but likely include $\mathrm{Cl}^{-}$input among other 
variables. Further research is needed to understand the processes behind $\mathrm{Cl}^{-}$retention and mineralization and its consequences on catchment $\mathrm{Cl}^{-}$budgets.

In conclusion, this synthesis of data indicates that $\mathrm{Cl}^{-}$may act as a conservative ion under conditions of high $\mathrm{Cl}^{-}$deposition, but not under condition of low deposition (less than about 6 $\mathrm{kg} \mathrm{ha}^{-1} \mathrm{yr}^{-1}$ ), and that processes controlling net retention and release of $\mathrm{Cl}^{-}$from plant and soil pools may be relatively more important in ecosystems with low or moderate $\mathrm{Cl}^{-}$deposition. These results highlight the need for better understanding of the processes of $\mathrm{Cl}^{-}$cycling in soils and vegetation.

\section{Acknowledgement}

We are grateful to the many scientists at the catchment and forest sites whose meticulous collection and publication of data made this study possible. Mary Beth Adams of the USDA Forest Service, Colin Neal of the Center for Ecology and Hydrology in the U.K., Sirpa Kleemola at Finnish Environment Institute, Gunilla Pihl-Karlsson at Swedish Environmental Research Institute, Reet Talkop at Estonian Environment Information Centre, Milan Vana at Czech Hydrometeorological Institute generously provided unpublished data, and Steve Norton, Lindsey Rustad, and Jake Peters helped us with discussions and interpretations of their data. We thank Chris Evans and Brian Reynolds for reviews that greatly improved the manuscript. Svensson is grateful for financial support from The Swedish Foundation for International Cooperation in Research and Education (STINT). Lovett was partially supported by the U.S. National Science Foundation through grant DEB-0342198 and DEB-0423259 and the Hubbard Brook LTER program. Long-term data provided by Likens for the Hubbard Brook Experimental forest were supported by the U.S. National Science Foundation, including the LTER and LTREB programs, and The Andrew W. Mellon Foundation. 


\section{References}

Alewell, C., G. Lischeid, U. Hell and G. Manderscheid (2004). High temporal resolution of ion fluxes in semi-natural ecosystems - gain of information or waste of resources? Biogeochemistry 69(1): 19-35.

Asplund, G., H. Borén, U. Carlsson and A. Grimvall (1991). Humic substances in the Aquatic and terrestrial Environment. Berlin, Springer Verlag.

Asplund, G., J. V. Christiansen and A. Grimvall (1993). A chloroperoxidase-like catalyst in soil: Detection and characterization of some properties. Soil Biology \& Biochemistry 25(1): 41-46.

Asplund, G. and A. Grimvall (1991). Organohalogens in nature. More widespread than prevoiusly assumed. Environmental Science \& Technology 25: 1347-1350.

Bailey, S. W., D. C. Buso and G. E. Likens (2003). Implications of sodium mass balance for interpreting the calcium cycle of a forested ecosystem. Ecology 84: 471-484.

Bastviken, D., P. Sandén, T. Svensson, C. Ståhlberg, M. Magounakis and G. Öberg (2006). Chloride retention and release in a boreal forest soil - effects of soil water residence time and nitrogen and chloride loads. Environmental Science and Technology 40: 2977-2982.

Bastviken, D., T. Svensson, S. Karlsson, P. Sandén and G. Öberg (2009). Temperature Sensitivity Indicates That Chlorination of Organic Matter in Forest Soil Is Primarily Biotic Environmental Science and Technology 43(10): 3569-3573.

Bastviken, D., F. Thomsen, T. Svensson, S. Karlsson, P. Sandén, G. Shaw, M. Matucha and G. Öberg (2007). Chloride retention in forest soil by microbial uptake and by natural chlorination of organic matter. Geochimica et Cosmochimica Acta 71(13): 3182-3192.

Buso, D. C., G. E. Likens and J. S. Eaton (2000). Chemistry of precipitation, streamwater, and lakewater from the Hubbard Brook Ecosystem Study: a record of sampling protocols and analytical procedures. General Technical Report NE-275: 1-52.

Campbell, K., A. Wolfsberg, J. Fabryka-Martin and D. Sweetkind (2003). Chlorine-36 data at Yucca Mountain: statistical tests of conceptual models for unsaturated-zone flow. Journal of Contaminant Hydrology 62-63: 43-61.

Castro, M. S. and R. P. Morgan (2000). Input-output budgets of major ions for a forested watershed in western Maryland. Water Air and Soil Pollution 119(1-4): 121-137.

Clutterbuck, P. W., S. L. Mukhopadhyay, A. E. Oxford and H. Raistrick (1940). Studies in the Biochemistry of microorganisms. The Biochemical Journal 34: 664-677.

Dimmer, C., P. Simmonds, G. Nickless and M. Bassford (2001). Biogenic fluxes of halomethanes from Irish peatland ecosystems. Atmospheric Environment 35: 321-330.

Eriksson, E. (1955). Air borne salts and the chemical composition of river waters. Tellus 7: 243-250.

Hedin, L. O., J. J. Armesto and A. H. Johnson (1995). Patterns of nutrient loss from unpolluted, old-growth temperate forests - evaluation of biogeochemical theory. Ecology 76(2): 493-509.

Hoekstra, E. J., J. H. Duyzer, E. W. B. d. Leer and U. A. T. Brinkman (2001). Chloroform concentration gradients in soil air and atmospheric air, and emission fluxes from soil. Atmospheric Environment 35: 61-70. 
Hultberg, H. and P. Grennfelt (1992). Sulfur and seasalt deposition as reflected by throughfall and runoff chemistry in forested catchments. Environmental Pollution 75(2): 215-222.

Johansson, E., G. Ebenå, P. Sandén, T. Svensson and G. Öberg (2001). Organic and inorganic chlorine in Swedish spruce forest soil: influence of nitrogen. Geoderma 101: 1-13.

Johansson, E., P. Sandén and G. Öberg (2003). Spatial patterns of organic chlorine and chloride in Swedish forest soil. Chemosphere 52: 391-397.

Johnson, N. M., G. E. Likens, F. H. Bormann, D. W. Fisher and R. S. Pierce (1969). A working model for the variation in stream water chemistry at the Hubbard Brook Experimental Forest, New Hampshire. Water Resources Research 5: 1353-1363.

Juang, F. and N. Johnson (1967). Cycling of chlorine through a forested watershed in New England. Journal of Geophysical Research 72(22): 5641-5647.

Kelly, V. R., G. M. Lovett, K. C. Weathers, S. E. G. Findlay, D. L. Strayer, D. J. Burns and G. E. Likens (2008). Long-term sodium chloride retention in a rural watershed: Legacy effects of road salt on streamwater concentration. Environmental Science and Technology 42(2): 410-415.

Kirchner, J. W. (2003). A double paradox in catchment hydrology and geochemistry. Hydrological Processes 17(4): 871-874.

Kram, P., J. Hruska, B. Wenne, C. Driscoll and C. Johnson (1997). The biogeochemistry of basic cations in two forest catchments with contrasting lithology in the Czech Republic. Biogeochemistry 37: 173-202.

Larsson, M. and N. Jarvis (1999). Evaluation of a dual-porosity model to predict field-scale solute transport in a macroporous soil. Journal of Hydrology 215: 153-171.

Lee, R., G. Shaw, P. Wadey and X. Wang (2001). Specific association of ${ }^{36} \mathrm{Cl}$ with low molecular wight humic substances in soil. Chemosphere 43: 1063-1070.

Likens, G. E. and F. H. Bormann (1995). Biochemistry of forested ecosystem, SpringerVerlag.

Lockwood, P., J. McGarity and J. Charley (1995). Measurement of chemical weathering rates using natural chloride as a tracer. Geoderma 64: 215-232.

Lovett, G. M. (1994). Atmospheric Deposition of Nutrients and Pollutants in North-America an Ecological Perspective. Ecological Applications 4(4): 629-650.

Lovett, G. M., G. E. Likens, D. C. Buso, C. T. Driscoll and S. W. Bailey (2005). The biogeochemistry of chlorine at Hubbard Brook, New Hampshire, USA.

Biogeochemistry 72(2): 191 - 232

Matzner, E., Ed. (2004). Biogeochemistry of forested catchments in a changing environment: a German case study. Ecological studies 172

Myneni, S. (2002). Formation of stable chlorinated hydrocarbons in weathering plant material. Science 295: 1039-1041.

Neal, C., B. Reynolds, M. Neal, H. Wickham, L. Hill and B. Williams (2004). The water quality of streams draining a plantation forest on gley soils: the Nant Tanllwyth, Plynlimon mid-Wales. Hydrology and Earth System Sciences 8(3): 485-502.

Neal, C., D. Robinson, B. Reynolds, M. Neal, P. Rowland, S. Grant, D. Norris, B. Williams, D. Sleep and A. Lawlor (2010). Hydrology and water quality of the headwaters of the River Severn: Stream acidity recovery and interactions with plantation forestry under an improving pollution climate. Science of the Total Environment 408: 5035-5051.

Nodvin, S. C., C. T. Driscoll and G. E. Likens (1986). Simple partitioning of anions and dissolved organic-carbon in a forest soil. Soil Science 142: 27-35. 
Ohrui, K. and M. J. Mitchell (1996). Elemental dynamics of a Japanese watershed with sugi (Cryptomeria japonica) and hinoki (Chamaecyparis obtusa) plantations. Canadian Journal of Forest Research 26: 2160-2169.

Ortiz-Bermudez, P., K. C. Hirth, E. Srebotnik and K. E. Hammel (2007). Chlorination of lignin by ubiquitous fungi has a likely role in global organochlorine production. Proceedings Of The National Academy Of Sciences Of The United States Of America 104(10): 3895-3900.

Peters, N. (1991). Chloride cycling in two forested lake watersheds in the west-central Adirondack Mountains, New York, USA. Water, Air and Soil pollution 59: 201-215.

Peters, N. E. and E. B. Ratcliffe (1998). Tracing hydrologic pathways using chloride at the Panola Mountain Research Watershed, Georgia, USA. Water, Air and Soil Pollution 105(1-2): 263-275.

Peters, N. E., E. B. Ratcliffe and M. Tranter (1998). Tracing solute mobility at the Panola Mountain Research Water shed, Georgia, USA: variations in $\mathrm{NA}^{+}, \mathrm{Cl}^{-}$and $\mathrm{H}_{4} \mathrm{SiO}_{4}$ concentrations. HeadWater'98 Conference, Italy, IAHS Press.

Peters, N. E., J. B. Shanley, B. T. Aulenbach, R. M. Webb, D. H. Campbell, R. Hunt, M. C. Larsen, R. F. Stallard, J. Troester and J. F. Walker (2006). Water and solute mass balance of five small, relatively undisturbed watersheds in the U.S. Science of the total environment 358: 221-243.

Probst, A., D. Viville, B. Fritz, B. Ambroise and E. Dambrine (1992). Hydrochemical budgets of a small forested granitic catchment exposed to acid deposition: The strengbach catchment case study (Vosges massif, France) Journal of Water, Air, \& Soil Pollution 62(3-4): 337-347.

Reynolds, B., D. Fowler, R. Smith and J. Hall (1997). Atmospheric inputs and catchment solute fluxes for major ions in five Welsh upland catchments. Journal of Hydrology 194: 305-329.

Rodstedth, M., C. Ståhlberg, P. Sandén and G. Öberg (2003). Chloride imbalances in soil lysimeters. Chemosphere 52: 381-389.

Rustad, L., J. Kahl, S. Norton and I. Fernandez (1994). Underestimation of dry deposition by throughfall in mixed northern hardwood forests Journal of hydrology 162(3-4).

Schlesinger, W. (1997). Biogeochemistry. An analysis of global change. San Diego, Academic Press.

Swank, W. and J. D. Crossley, Eds. (1988). Ecological Studies 66: Forest hydrology and ecology at Coweeta Springer Verlag.

Svensson, T., P. Sandén, D. Bastviken and G. Öberg (2007). Chlorine transport in a small catchment in southeast Sweden during two years. Biogeochemistry 82: 181-199.

Winterton, N. (2000). Chlorine: the only green element - towards a wider acceptance of its role in natural cycles. Green Chemistry 2: 173-225.

Öberg, G. (2002). The natural chlorine cycle - fitting the scattered pieces. Applied Microbiology and Biotechnology 58: 565-581.

Öberg, G. and C. Grön (1998). Sources of organic halogens in a Danish spruce forest soil. Environmental Science and Technology 32: 1573-1579.

Öberg, G., M. Holm, P. Sandén, T. Svensson and M. Parikka (2005a). The role of organicmatter-bound chlorine in the chlorine cycle: a case study of the Stubbetorp catchment, Sweden. Biogeochemistry 75: 241-269.

Öberg, G. and P. Sandén (2005b). Retention of chloride in soil and cycling of organic matterbound chlorine. Hydrological Processes 19: 2123-2136 


\section{Table}

Table 1. Description of the catchment sites in the study. Deposition sampling method: TF (throughfall), BD (bulk deposition), WD (wet deposition only). 